\title{
Dietary levels of all-trans retinol affect retinoid nuclear receptor expression and skeletal development in European sea bass larvae
}

\author{
Laure Villeneuve $^{1 *}$, Enric Gisbert ${ }^{1,2}$, Hervé Le Delliou ${ }^{1}$, Chantal L. Cahu ${ }^{1}$ and Jose L. Zambonino-Infante ${ }^{1}$ \\ ${ }^{1}$ Unité Mixte de Nutrition des Poissons IFREMER-INRA, IFREMER, 29280 Plouzané, France \\ ${ }^{2}$ Centre d'Aqüicultura, Institut de Recerca i Tecnologia Agroalimentaries (IRTA), Aptat. Correus 200, 43540 Sant Carles de la Ràpita, \\ Tarragona, Spain
}

(Received 29 June 2004 - Revised 24 November 2004 - Accepted 5 January 2005)

European sea bass larvae were fed different dietary vitamin A levels. Growth, skeletal development and the expression of genes involved in larval morphogenesis were evaluated. From 7 to $42 \mathrm{~d}$ post-hatching, larvae were fed five isoproteic and isolipidic compound diets with graded levels of retinyl acetate (RA; RA0, RA10, RA50, RA250 and RA1000, containing 0, 10, 50, 250 and $1000 \mathrm{mg} \mathrm{RA} / \mathrm{kg}$ DM, respectively), resulting in an incorporation of 12, 13, 31, 62 and $196 \mathrm{mg}$ all-trans retinol/kg DM. Larvae fed extreme levels of RA had weights $19 \%$ and $27 \%$ lower than those of the RA50 group. The RA1000 diet induced a fall in growth with an increase of circulating and storage retinol forms in larvae, revealing hypervitaminosis. High levels of RA affected maturation of the pancreas and intestine. These data indicated that the optimal RA level was close to $31 \mathrm{mg} / \mathrm{kg}$ DM. Inappropriate levels of dietary RA resulted in an alteration of head organisation characterised by the abnormal development of the splanchnocranium and neurocranium, and scoliotic fish. Of the larvae fed RA1000, 78.8\% exhibited skeletal abnormalities, whereas the RA50 group presented with $25 \%$ malformations. A linear correlation between vitamin A level and malformation percentage was observed and mainly associated with an upregulation of retinoic acid receptor- $\gamma$ expression in the RA1000 group during the 2 first weeks after hatching. The expression of retinoid X receptor- $\alpha$ decreased during normal larval development when that of the retinoic acid receptors increased. This work highlights the involvement of retinoid pathways in the appearance of dietary-induced skeletal malformations during posthatching development in sea bass.

Retinol: European sea bass: Skeletal malformations: Retinoic acid nuclear receptors (RAR, RXR): Growth factors (BMP-4, IGF-1)

During the first weeks of life, marine fish larvae undergo significant morphological and physiological modifications to acquire all the adult features by the end of the larval period. Several factors can interfere with the normal development of larvae and affect their quality, which can be defined as the capacity to continue a normal development until the juvenile and adult stages (Cahu et al. 2003b). Skeletal deformities of fish larvae can be due to many parameters in hatcheries, for example the hydrodynamics in the tanks, inadequate light intensity, water temperature and salinity, and an unbalanced diet (Cahu et al. 2003b). The ingestion of an inadequate diet may delay or prevent the genetically programmed sequence of body development, including skeletal patterning and intestinal maturation (Dedi et al. 1997; Zambonino Infante et al. 1997; Reifen et al. 1998; Uni et al. 2000; Cahu et al. 2003a,b; Haga et al. 2003). Up until now, owing to the absence of a compound diet (Cahu et al. 2003a), marine fish larvae were fed at mouth opening with live prey, which did not allow accurate experiments on their nutritional requirements to be conducted. The recent development of a balanced compound diet has made it possible to study the influence of the nature, molecular form and level of dietary nutrients.
There is a close relationship between larval nutrition at first feeding and skeletal abnormalities (Zambonino Infante et al. 1997, 1999; Suzuki et al. 2000). It is well known that genes involved in body patterning can be regulated by the nature and molecular form of the nutrients (Krumlauf, 1994; Suzuki et al. 1998, 2000; Balmer \& Blomhoff, 2002; Haga et al. 2003). Generally, marine fish larvae hatch much earlier in their development than other vertebrates, suggesting that the spatiotemporal sequences of the skeletal development in teleosts are quite different from those of higher vertebrates (Haga et al. 2002). Therefore, marine fish species let us study the molecular processes influenced by nutrition and involved in the appearance of skeletal malformations in the early stages of teleost development. In order to study the relationship between skeletal malformations and dietary nutrients, we have chosen a nutrient, vitamin A, which is known to have teratogenic effects in vertebrates at inappropriate dietary levels. This work on vitamin A may provide an understanding of some of the cellular mechanisms influenced by nutrition and involved in the onset of deformities in marine fish, and allow the expansion of this study to other nutrients also implicated in skeletal abnormalities. 
Data on dietary vitamin A requirements for marine fish are scarce (Gouillou-Coustans \& Guillaume, 2001). Retinoids, which are vitamin A-related compounds, regulate a wide variety of biological functions, including cell differentiation, proliferation and morphogenesis (Haga et al. 2002). The biological activity of vitamin A is mediated mainly by its active metabolite, retinoic acid. There are two active forms of retinoic acid, 9-cis and alltrans retinoic acid, which are obtained by the dehydrogenation of vitamin A (Gouillou-Coustans \& Guillaume, 2001). Several studies have shown that an excess of dietary vitamin A results in abnormalities during embryogenesis in mammals (Cohlan, 1953), birds (Lee et al. 2001), amphibians (Minucci et al. 1996) and fish (Dedi et al. 1997; Ornsrud et al. 2002). The biological effects of retinoids (vitamin A metabolites) are exerted mainly through the activation of two groups of nuclear receptor, retinoic acid receptors (RAR) and retinoid X receptors (RXR), which usually exist under three sub-families $(\alpha, \beta$ and $\gamma$; Ross et al. 2000). The RXR bind to 9-cis retinoic acid, whereas the RAR bind both to all-trans and 9-cis retinoic acid (Ross et al. 2000). These receptors can dimerise together, and RXR can also heterodimerise with other types of nuclear receptor (Yu et al. 1991). These heterodimers can bind to the response elements of fatty acids, vitamin D and thyroid hormones, or to specific retinoic acid response elements localised on target genes, and thereby suppress or enhance the transcription of more than 500 genes either directly or indirectly (Balmer \& Blomhoff, 2002).

Retinoic acid is essential for initiating the expression of Hox or sonic hedgehog (shh) gene families that are involved in tissue development and differentiation (Joore et al. 1994; Krumlauf, 1994; Conlon, 1995; Haga et al. 2002). Skeletal patterning, bone development and limb morphogenesis are also regulated by other gene families, including bone morphogenetic proteins (BMP) and insulin-like growth factors (IGF). BMP are multifunctional regulators of vertebrate development, regulating cell proliferation, determination, differentiation, morphogenesis and apoptosis (Hogan, 1996). IGF-1 is a mitogenic agent acting as not only a growth-promoting, but also a differentiation factor in bone, muscle and cartilage (Zizola et al. 2002). Both an excess and a deficiency of vitamin A, which disrupt the retinoid-signalling pathway including the above-mentioned gene families, lead to abnormal development of the heart, bone, craniofacial structures, central nervous system, pigment cells and axis formation in vertebrate embryos (Helms et al. 1997; Ross et al. 2000; Suzuki et al. 2000; Gouillou-Coustans \& Guillaume, 2001; Haga et al. 2002). The signalling pathways described above are well known in higher vertebrates, but it is still unclear whether they are functional in marine fish after hatching and whether they can be modulated by nutrition.

The aims of the present study were (1) to evaluate the effect of different vitamin A dietary levels on fish development, in terms of optimal growth, intestinal maturation and incidence of skeletal malformations, (2) to provide an insight into dietary larval requirements, and (3) to study the influence of vitamin $\mathrm{A}$ on gene expression during European sea bass larval morphogenesis.

\section{Materials and methods}

\section{Animals and diets}

Three-day old European sea bass (Dicentrarchus labrax) larvae were obtained from the Ecloserie Marine de Gravelines
(Gravelines, France) and shipped to the Fish Nutrition Laboratory at the Ifremer (Centre de Brest), where they were acclimated and divided into fifteen cylindroconical fibreglass tanks (35 litres) at a initial density of sixty larvae per litre. Tanks were supplied with running sea water, which had been previously filtered through a sand filter and then passed successively through a tungsten heater and a degassing column packed with plastic rings. Throughout the experiment, the water temperature and salinity were $20^{\circ} \mathrm{C}$ and $35 \%$, respectively, and the oxygen level was maintained above $6 \mathrm{mg} / \mathrm{l}$ by setting the water exchange of the tank up to $30 \%$ per $\mathrm{h}$ (flow rate $0 \cdot 18 \mathrm{l} / \mathrm{min}$ ). The photoperiod was 24 light:0 dark, and light intensity was $9 \mathrm{~W} / \mathrm{m}^{2}$ maximum at the water surface. All animal procedures and handling were conducted in compliance with the Guide for the Care and Use of Laboratory Animal (National Research Council (1985)).

At $4 \mathrm{~d}$ post-hatching (dph), larvae were divided into five experimental groups (three tanks per group) that were fed from 7 dph with experimental compound microdiets (Table 1) containing graded level of all-trans retinyl acetate (RA; 500000 USP units/g; Sigma-Aldrich, St Louis, MD, USA). Diets containing $0,10,50,250$ and $1000 \mathrm{mg}$ of added RA/kg DM were designated RA0, RA10, RA50, RA250 and RA1000, respectively. For comparative purposes, the RA50 diet was considered as the control. The size of the microdiet was $200-400 \mu \mathrm{m}$. During the experimental period, larvae were continuously fed in large excess for $24 \mathrm{~h}$ daily using a belt feeder. At the end of the trial $(42 \mathrm{dph})$, fish fed with the same experimental diet were pooled and transferred to a 700 litre square fibreglass tank (one tank per diet) and reared until $80 \mathrm{dph}$ under the above-mentioned environmental conditions. During this period, all fish were fed with the same commercial diet (Neo Soupra AL4; Le Gouessant, Lamballe, France) containing $58 \%$ protein, $13 \%$ lipid, $12 \%$ ash and $1.2 \%$ cellulose (proximate composition provided by the feed manufacturer).

Table 1. Composition of the experimental compound microdiet

\begin{tabular}{lc}
\hline Ingredients $^{*}$ & $\mathrm{~g} / \mathrm{kg} \mathrm{DM}$ \\
\hline Fish meal & 579 \\
Hydrolysed fish meal & 140 \\
Soya lecithin & 151 \\
Vitamin mixture† (without retinyl acetate) & 80 \\
Mineral mixture & 40 \\
Betaine & 10 \\
Proximate composition & $\%$ \\
Proteins $(\mathrm{N} \times 6 \cdot 25)$ & 53.0 \\
Lipids & 18.1 \\
Ash & 11.5 \\
Humidity & 10.0 \\
Energy $(\mathrm{kJ} / \mathrm{kg}) \S$ & 15.67
\end{tabular}

*All dietary ingredients were commercially obtained: fish meal (La Lorientaise, Lorient, France), hydrolysed fish meal (CPSP G, Soluble Fish Protein Concentrate, Sopropêche, Boulogne sur Mer, France), soya lecithin (Ets Louis François, St Maur des Fossés, France).

†Composition / $\mathrm{kg}$ vitamin mixture: choline concentrate $50 \% 200 \mathrm{~g}$, vitamin E $(500 \mathrm{Ul} / \mathrm{g})$ $10 \mathrm{~g}$, vitamin $D_{3}(500000 \mathrm{Ul} / \mathrm{g}) 500 \mathrm{mg}$, vitamin $B_{3} 1 \mathrm{~g}$, vitamin $B_{5} 2 \mathrm{~g}$, vitamin $B_{1}$ $100 \mathrm{mg}$, vitamin $B_{2} 400 \mathrm{mg}$, vitamin $B_{6} 300 \mathrm{mg}$, vitamin $C 20 \mathrm{~g}$, vitamin $B_{9} 100 \mathrm{mg}$, vitamin concentrate $B_{12}(1 \mathrm{~g} / \mathrm{kg}) 1 \mathrm{~g}$, biotin $1 \mathrm{~g}$, vitamin $K_{3} 1 \mathrm{~g}$, meso-inositol $30 \mathrm{~g}$, cellulose $7321 \mathrm{~g}$.

‡Composition / kg mineral mixture: $\mathrm{KCl} 90 \mathrm{~g}, \mathrm{Kl}_{4} \mathrm{O} 40 \mathrm{mg}, \mathrm{CaHPO}_{4} 2 \mathrm{H}_{2} \mathrm{O} 500 \mathrm{~g}, \mathrm{NaCl}$ $40 \mathrm{~g}, \mathrm{CuSO}_{4} 5 \mathrm{H}_{2} \mathrm{O} 3 \mathrm{~g}, \mathrm{ZnSO}_{4} 7 \mathrm{H}_{2} \mathrm{O} 4 \mathrm{~g}, \mathrm{CoSO}_{4} 7 \mathrm{H}_{2} \mathrm{O} 20 \mathrm{mg}, \mathrm{FeSO}_{4} 7 \mathrm{H}_{2} \mathrm{O} 20 \mathrm{~g}$, $\mathrm{MnSO}_{4} \mathrm{H}_{2} \mathrm{O} 3 \mathrm{~g}, \mathrm{CaCO}_{3} 215 \mathrm{~g}, \mathrm{MgSO}_{4} 7 \mathrm{H}_{2} \mathrm{O} 124 \mathrm{~g}, \mathrm{NaF} 1 \mathrm{~g}$.

$\S$ Calculated as: total carbohydrate $\times 16.7 \mathrm{~J} / \mathrm{kg}$, fat $\times 37.7 \mathrm{~J} / \mathrm{kg}$, protein $\times 16.7 \mathrm{~J} / \mathrm{kg}$ 
Sampling

To evaluate growth, ten specimens were randomly sampled from each experimental tank ( $n 30$ per experimental diet) at 28, 37 and $42 \mathrm{dph}$, and killed with an overdose of tricaine methanesulphonate (MS 222), their body weight being measured to the nearest $0.1 \mathrm{mg}$. To evaluate the level of maturation of the digestive system, larvae (n 20-50, depending on body weight) were sampled from each tank and kept at $-20^{\circ} \mathrm{C}$ until analysis. Samples for measuring brush border intestinal enzymes were taken at 28 and $42 \mathrm{dph}$, whereas pancreatic enzyme activities were measured only at $42 \mathrm{dph}$. Fifty larvae were collected for messenger RNA studies from the RA0, RA50 and RA1000 experimental tanks at 10, 15, 21 and $42 \mathrm{dph}$, and the total RNA was immediately extracted from total-body homogenate. The same number of fish were sampled at 2, 10, 15, 21, 37 and $42 \mathrm{dph}$ and frozen at $-80^{\circ} \mathrm{C}$ in order to evaluate retinol (the active transport form) and retinyl palmitate (the storage form of retinol) in fish fed different levels of RA. In all cases, sampling procedures were performed as previously described (Cahu et al. 2003a). The incidence of body skeletal malformations (splanchnocranium, neurocranium and vertebral column deformities) was counted at $87 \mathrm{dph}$ ( $n 80$ per experimental diet) (Fig. 1). At the end of the rearing period ( $42 \mathrm{dph}$ ), larval survival was calculated as the percentage of surviving individuals in relation to the initial number of larvae. From $15 \mathrm{dph}$ onwards, samplings accounted for the determination of larval survival; indeed, the critical stage of development corresponding to resorption of the yolk sac and a high mortality rate has been overcome after 15 dph (Barnabé et al. 1976).

\section{Analytical methods}

Larvae were dissected under a binocular microscope at $0^{\circ} \mathrm{C}$ as previously described (Cahu et al. 2003a). Individuals were cut into four parts - head, pancreatic segment (PS), intestinal segment (IS) and tail - in order to limit the assay of enzymes to specific segments. This dissection inevitably produced a crude mixture of organs in each segment. The PS contained, besides the pancreas, the liver, heart, muscle and spine. The IS contained

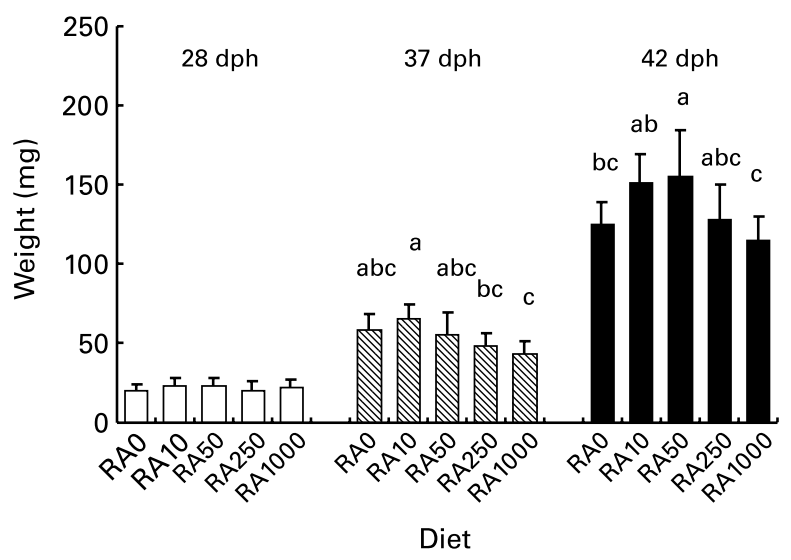

Fig. 1. Growth of European sea bass larvae fed isonitrogenous diets containing different all-trans retinol levels. Values shown are means for three samples with their standard errors shown by vertical bars, and different superscript letters for the same day designate significant differences $(P<0.05)$. the intestine, muscle and spine. Once dissected, PS were homogenized in five volumes $(\mathrm{v} / \mathrm{w})$ of ice-cold distilled water. Trypsin (EC 3.4.21.4) activity was measured using Na-benzoyl-DL-arginine- $p$-nitroaniline as substrate (Holm et al. 1988) in both PS and IS. Purified brush border membranes from the IS were obtained according to a method developed for intestinal scraping (Crane et al. 1979). The degree of purification of the brush border membrane, considering alkaline phosphatase and aminopeptidase $\mathrm{N}$ as markers of cell membrane fraction, was close to that reported in the literature (Crane et al. 1979), i.e. 13.5-fold and 10-fold, respectively. Alkaline phosphatase (EC 3.1.3.1), aminopeptidase $\mathrm{N}$ ( $E C$ 3.4.11.2) and maltase ( $E C$ 3.2.1.20), three enzymes of the intestinal brush border membrane, were quantified using $p$-nitrophenylphosphate, L-leucine- $p$-nitroaniline and $\mathrm{D}(+)$ maltose, respectively, as substrates (Bessey et al. 1946; Maroux et al. 1973; Dahlqvist, 1970). Specific enzyme activities were expressed as $\mu \mathrm{mol}$ of substrate hydrolysed per min and per $\mathrm{mg}$ protein (U/mg protein), and protein was determined using the Bradford method (Bradford, 1976). The ratio of the trypsin activity in the IS related to total activity (PS + IS) was calculated, considering that enzyme activity in the PS can be used as an index of the synthetic function of pancreas, and that in the IS can be used as an index of pancreatic secretory function (Zambonino Infante et al. 1997). This ratio reflected the trypsin secretion rate.

Retinol and retinyl palmitate were extracted from non-dissected larvae that were homogenised with a PBS solution by means of a Polytron MR 2100 (Kinematica AG, Luzern, Switzerland). Then, $1 \mathrm{ml}$ homogenate was transferred into a dark brown tube, and $1 \mathrm{ml}$ ethanol (containing $50 \mu \mathrm{g} / \mathrm{l}$ 2,6-di-tert-butyl-4-methylphenol), the internal standard and $2 \mathrm{ml}$ hexane (containing $50 \mu \mathrm{g} / \mathrm{l}$ 2,6-di-tertbutyl-4-methylphenol) were added (Grolier et al. 1995). After mixing the solution for $1 \mathrm{~min}$, the organic layer was separated by centrifugation $(5 \mathrm{~min}$ at $2000 \mathrm{~g}$ ). After that, the organic layer was collected in another dark brown tube, which was flushed with $\mathrm{N}_{2}$ gas until the residue was completely dry. This operation was repeated twice, and the residue was collected and dissolved in methanol for retinol and retinyl palmitate determination by HPLC. The HPLC system consisted of a Waters 600E (Waters, Milford, MA, USA) apparatus with UV detection at $325 \mathrm{~nm}$ (Waters 486, Tunable Absorvance Detector; Waters) and a C18 novapack $30 \mathrm{~cm}$ column (Waters). Retinol and retinyl palmitate were quantified using internal and external standards (retinyl acetate; Sigma-Aldrich).

\section{RT-PCR analysis}

Different complementary DNA fragments of genes coding for RAR and for signalling molecules known for interacting with retinoic acid were purified in European sea bass larvae by RT-PCR, cloned, sequenced and registered by the European Molecular Biology Laboratory: RXR $\alpha$ (accession number AJ 567907), RAR $\alpha$ (AJ 496189), RAR $\gamma$ (AJ 496181), BMP-4 (AJ 567451) and IGF-1 (AJ 579342). Glyceraldehyde-3-phosphate deshydrogenase (AJ 567450) was chosen as the house-keeping gene.

\section{Real-time RT-PCR}

Complementary DNA samples were treated with DNase, and real-time PCR was performed using the iCycler iQ (Bio-Rad Laboratories Inc. Hercules, CA, USA). Quantitative PCR analyses for each gene were performed in a total volume of 
$15 \mu \mathrm{l}$ containing $5 \mu \mathrm{l}$ complementary DNA (dilution $10^{-3}$ ), $1.5 \mu \mathrm{l}$ fluorescein (100 nmol/1; Bio-Rad Laboratories Inc.), $1 \mu$ primers $(10 \mu \mathrm{mol} / \mathrm{l})$ and $7.5 \mu \mathrm{l}$ QuantiTect SYBR Green PCR Master Mix 2X (Qiagen GmbH, Hilden, Germany). For each target gene, forward and reverse primers (Table 2) were chosen in the sequences previously cloned. Thermal cycling was initiated with incubation at $95^{\circ} \mathrm{C}$ for $13.5 \mathrm{~min}$ for activation of HotStarTaq DNA polymerase (Qiagen). After this initial step, 45 cycles of PCR were performed. Each PCR cycle consisted of heating at $95^{\circ} \mathrm{C}$ for $30 \mathrm{~s}$ for denaturing and then at $60^{\circ} \mathrm{C}$ for $1 \mathrm{~min}$ for annealing and extension. Cycle threshold values corresponded to the number of cycles at which the fluorescence emission monitored in real time exceeded the threshold limit. Melting curve analysis was performed to confirm the production of a single product in these reactions, and these products were sequenced by MilleGen (Labège, France). Standard curves were established for each gene by plotting the cycle threshold values against the $\log _{10}$ of five different dilutions (in triplicate) of complementary DNA sample solutions. The efficiency of real-time PCR efficiency (E) determined for each gene from the given slopes in Bio-Rad software, according to the equation $\mathrm{E}=10^{[-1 / \text { slope }]}$. We calculated the relative expression ratio of each gene using REST software (http://www.wzw.tum.de/gene-quantification/). The relative expression ratio for a considered gene is based on the PCR efficiency (E) and the cycle threshold (CT) of a sample (RA0 or RA1000) $v$. the control (RA50), and expressed in comparison to the reference gene (glyceraldehyde-3-phosphate deshydrogenase; GAPDH), according to Pfaffl's mathematical model (Pfaffl, 2001):

ratio $=\left[\left(\mathrm{E}_{\text {gene }}\right)^{\Delta \mathrm{CT}_{\text {gene }}(\text { control-sample })}\right] /\left[\left(\mathrm{E}_{\mathrm{GAPDH}}\right)^{\Delta \mathrm{CT}_{\mathrm{GAPDH}}(\text { control-sample })}\right]$

Normalisation relative to GAPDH provided a widely applicable value for comparative studies of gene expression at the messenger RNA level, since its expression is constant during the activation and proliferation of cells (Gause \& Adamovicz, 1994).

\section{Statistical analyses}

Results are given as means together with their standard deviations. All data were checked for variance homogeneity using Barlett's test (Dagnelie, 1975). Growth, enzymatic specific activity and $\arcsin \left(\mathrm{x}^{1 /}\right.$ ${ }^{2}$ )-transformed trypsin secretion ratio were compared by means of a one-way ANOVA followed by the Student Newman Keuls multiple range test when significant differences were detected $(P<0.05)$. Statistical differences in gene expression between control and samples were evaluated in group means by 2000 randomisation tests with a pair-wise reallocation (Pfaffl et al. 2002) using REST software, and differences were considered significant at $P=0 \cdot 05$.

\section{Results}

\section{Growth and survival}

At the beginning of the exogenous feeding period $(9 \mathrm{dph})$, larval body weight was $0.8(0.05) \mathrm{mg}$. No statistically significant differences were observed between fish fed with diets containing different levels of retinol up to $30 \mathrm{dph}(22.0(1.53) \mathrm{mg} ; P>0.05)$. At day 37 , the highest body weight was observed for larvae fed RA0, RA10 and RA50, whereas growth was significantly lower in larvae fed RA1000 $(P<0.05)$ (Fig. 1). At the end of the larval rearing period (42 dph), intermediate dietary levels of RA (RA50) resulted in higher weight values, in contrast to larvae fed extreme concentrations of retinol (RA0, RA1000) $(P<0 \cdot 05)$.

At $42 \mathrm{dph}$, fish fed RA50 and RA10 exhibited the highest survival percentages $(P<0.05)$, i.e. $62(5.7) \%$ and $68(7.7) \%$ respectively; survival in fish fed with RA0, RA250 and RA1000 was not significantly different $(40(6 \cdot 8) \%, 41(7 \cdot 2) \%$ and $46(7 \cdot 8) \%$, respectively).

\section{Retinol and retinol palmitate diet and larval content}

Analysis of the retinol content of the tested diets showed that the real incorporated level of all-trans retinol was 12, 13, 31, 62 and $196 \mathrm{mg} / \mathrm{kg}$ DM for the RA0, RA10, RA50, RA250 and RA1000 diets, respectively.

At the end of the rearing period ( $42 \mathrm{dph}$ ), no statistically significant differences in retinol body content were detected between fish fed RA0, RA10, RA50 and RA250 (18.2 (SD 1.93) $\mu \mathrm{g} / 100 \mathrm{~g}$ ). The above-mentioned values were significantly lower than those obtained with RA1000 (26.4 (SD 6.90) $\mu \mathrm{g} / 100 \mathrm{~g} ; \quad P<0.05$ ) (Fig. 2(a)).

The diets were consumed as soon as the microparticles reached the tank water. The accumulation of retinyl palmitate in developing larvae was dependent on the level of retinol administered by the experimental diets, reaching a plateau at $15 \mathrm{dph}$ (Fig. 2(b)). A linear correlation was established at $42 \mathrm{dph}$ between dietary RA concentration and the level of retinyl palmitate found in the larvae $\left(y=0.455 x+23.685 ; R^{2}=0.987, P<0.0006\right)$. At $42 \mathrm{dph}$, no statistically significant differences were detected between the levels of retinyl palmitate in larvae fed diets containing $0,10,50$ and $250 \mathrm{mg}$ retinyl acetate $/ \mathrm{kg} \mathrm{DM}(P>0.05)$. The values of retinyl palmitate in larvae fed RA1000 were significantly higher than those measured in the rest of the dietary groups (109.4 (SD 32.20) v. 37.2 (SD 14.02) $\mu \mathrm{g} / 100 \mathrm{~g} ; P<0.05$ ).

\section{Skeletal malformations}

The incidence of skeletal malformations in European sea bass juveniles (age $87 \mathrm{dph}$, mean weight $4.4(0.41) \mathrm{g}$ ) are presented in Figs. 3(a) and 4. Among the four types of malformation

Table 2. Nucleotide sequences of the PCR primers used to assay gene expression by real-time quantitative PCR.

\begin{tabular}{lll}
\hline Gene & Forward primer & Reverse primer \\
\hline Glyceraldehyde-3-phosphate deshydrogenase & GAGGTCAAGGTTGAGGGTGA & CCAGTGGACTCAACCACGTA \\
Retinoid X receptor- $\alpha$ & CTGGTAGAGTGGGCCAAGAG & GTTCTGTGAGCACCCTGTCA \\
Retinoic acid receptor- $\alpha$ & CGCTAAACCGAACCCAGA & CTTCTCGGCCTGTTCCAA \\
Retinoic acid receptor- $\gamma$ & GCAAAGCTCACCAAGAGACC & GCGTAGTGAAGCCTGGTAGC \\
Bone morphogenetic protein-4 & CTGCTCTCTTCCGCTGAACT & GGCTCACATCAAAGCTCTCC \\
Insulin-like growth factor-1 & GTCTTGGCAGGTGCACAGTA & ACACGCTGCAGTTTGTGTT \\
\end{tabular}



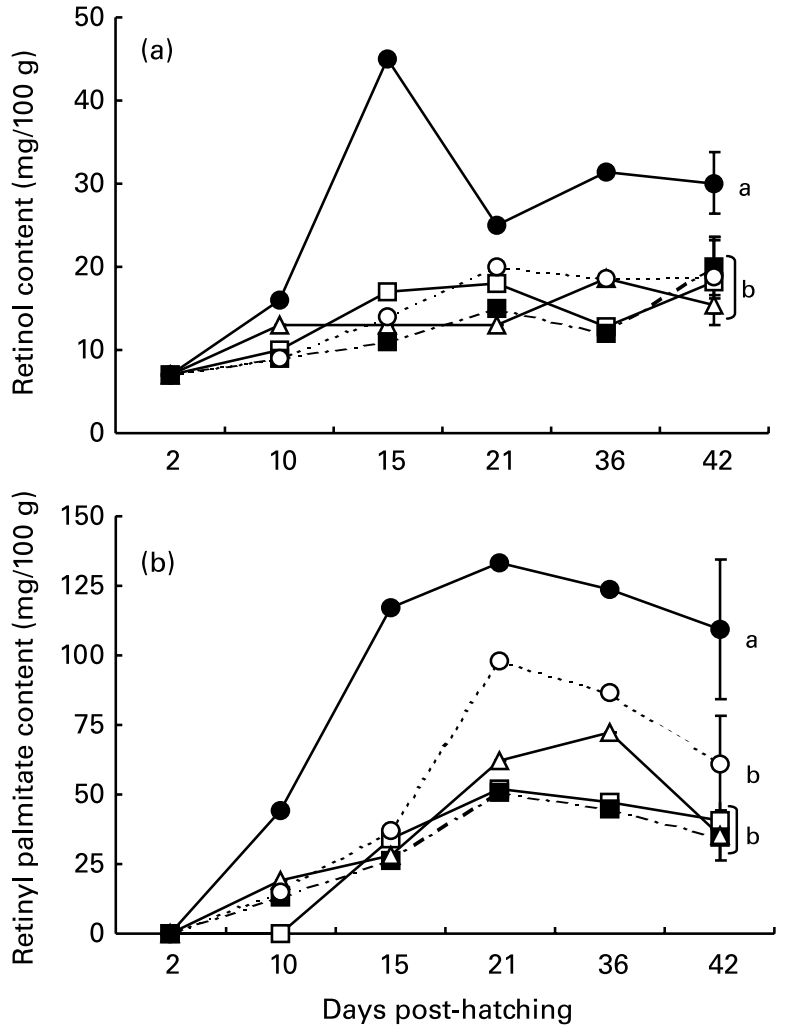

Fig. 2. Levels of retinol (a) and retinyl palmitate (b) in European sea bass larvae fed isonitrogenous diets containing different all-trans retinol levels ( $\square$, RA0; , RA10; $\triangle$, RA50; O, RA250; •, RA1000) at different stages of development. Only means for three samples with standard deviation shown by vertical bars are presented for larvae aged 42 days post-hatching. Different superscript letters for the same day designate significant differences $(P<0.05)$. RA, retinyl acetate.

observed, underdevelopment of the neurocranium and splanchnocranium (especially the maxillary bones and operculum) showed the highest incidence in all experimental groups, especially in fish with the highest level of retinyl palmitate (RA1000). A significant linear relationship was shown between the retinyl palmitate level in the $42 \mathrm{dph}$ larvae and the incidence of malformations in the fish (Fig. 3(b)).

The correlation coefficients between retinyl palmitate concentrations in the larvae and the incidence of skeletal malformations in the splanchnocranium, neurocranium and vertebral column are presented in Table 3. The presence of deformities in the neurocranium and splanchnocranium (maxilla and operculum) was strongly correlated to the level of retinyl palmitate in the larvae, whereas no statistically significant correlation was observed between the incidence of deformities in the vertebral column and the retinyl palmitate level.

\section{Enzyme activities}

The level of RA in the diet induced statistically significant differences in the trypsin secretion ratio at $42 \mathrm{dph}(P<0.05)$. The highest trypsin secretion ratio (54.6 (2.99) \%) was observed in fish fed RA50, whereas the lowest values were those of fish fed RA1000 (40.7 (2.89) \%; $P<0.05)$. Intermediate trypsin secretion ratios were observed for larvae fed RA0 (47.5 (1.47)\%), RA10 (46.8 $(5 \cdot 71) \%)$ and RA250 (46.2 (4.26) \%).
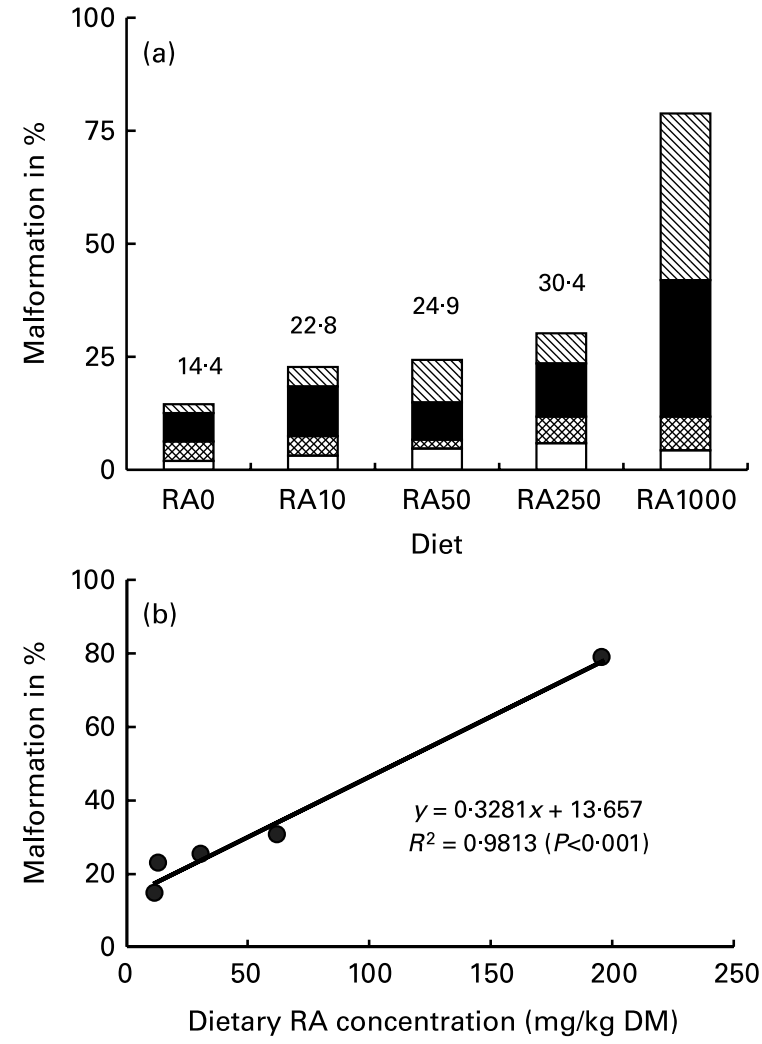

Fig. 3. Incidence of skeletal malformations (a) and linear correlation between dietary levels of all-trans retinol and percentage of malformation (b) in European sea bass larvae fed isonitrogenous diets containing different doses of all-trans retinol. ( $\square$ ) Vertebral column, (网) Operculum, (ם) Maxilla, (四) Neurocranium.

The specific activity of intestinal brush border enzymes was also affected by the dietary content of RA (Fig. 5). At 28 dph, the alkaline phosphatase specific activity was $40 \%$ higher in fish fed RA50 and RA250 (1254 (SD 153.1) and 1262 (SD 85.7) $\mathrm{mU} / \mathrm{mg}$ protein, respectively) than in those fed RA0 (549 (SD 47.1) $\mathrm{mU} / \mathrm{mg}$ protein), whereas intermediate specific activities were detected in fish fed RA10 and RA1000 (829 (SD 153.1) and 884 (SD 94.3) mU/mg protein, respectively). At the end of the larval rearing period, no statistically significant differences were observed between fish fed different levels of retinyl acetate $(P>0 \cdot 05$; Fig. 5(a)).

Aminopeptidase and maltase specific activities followed the same trend as that of alkaline phosphatase. At $28 \mathrm{dph}$, the aminopeptidase and maltase specific activity in fish fed RA0 was $50 \%$ lower than those reared with RA50 (140 (SD 41.9) v. 284 (SD $33.4) \mathrm{mU} / \mathrm{mg}$ protein and $102(\mathrm{SD} 24.7)$ v. 207 (SD 35.6) $\mathrm{mU} /$ $\mathrm{mg}$ protein, respectively $(P<0.05)$. The rest of the experimental groups showed intermediate enzymatic activities with respect to the control group (Fig. 5(b), (c)). At 42 dph, no statistically significant differences in enzymatic specific activity were observed between fish fed different diets $(P>0 \cdot 05)$.

\section{Gene expression}

Effect of development on gene expression in RA50 diet. Gene expression at $42 \mathrm{dph}$ was compared with that at $10 \mathrm{dph}$ in fish fed RA50 (Fig. 6). At $42 \mathrm{dph}$, the two sub-types of RAR studied were significantly upregulated by a factor of $7.27(P<0.05)$ and $35.56(P<0.05)$, respectively, whereas RXR $\alpha$ was downregulated 

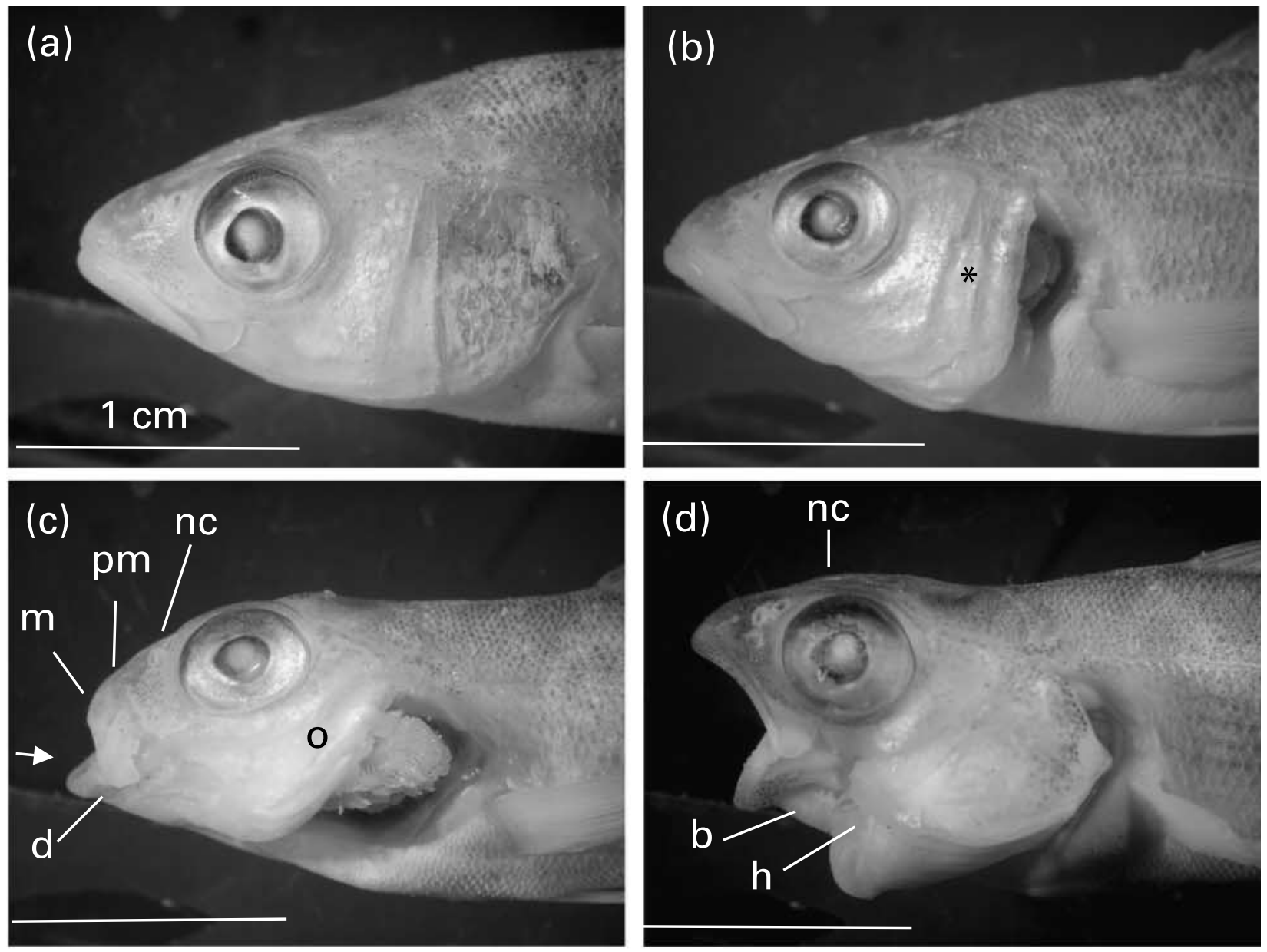

(e)

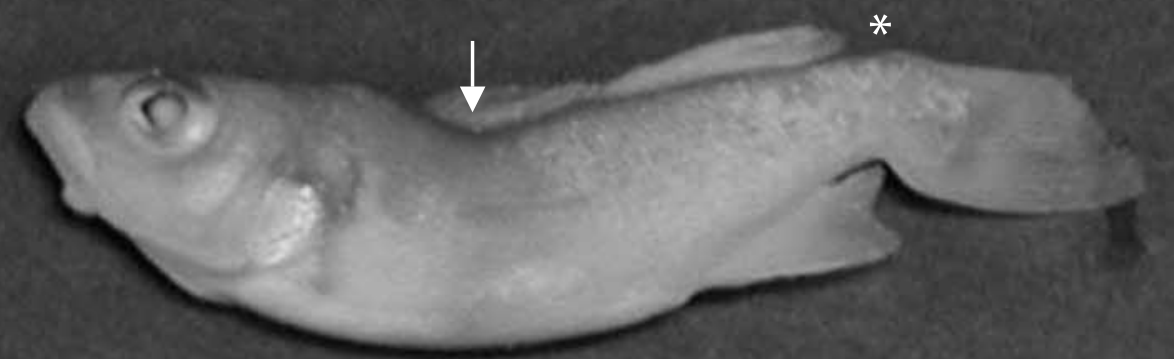

$1 \mathrm{~cm}$ 
Table 3. Correlation (Pearson product moment correlation) between the levels of retinyl acetate (RA) in the diet and the incidence of different skeletal deformities in European sea bass (Dicentrarchus labrax) juveniles (87 days post-hatching).

\begin{tabular}{lcc}
\hline & \multicolumn{2}{c}{ Dietary RA } \\
\cline { 2 - 3 } Variable & $r$ & $P$ \\
\hline Dietary RA & 1.000 & 0.000 \\
Neurocranium & 0.955 & 0.003 \\
Splanchnocranium & 0.951 & 0.005 \\
Operculum & 0.992 & 0.004 \\
Vertebral column & 0.386 & 0.579 \\
\hline
\end{tabular}

35.44-fold $(P<0 \cdot 05)$. BMP-4 and IGF expression remained at the same level during this period.

Effect of experimental diets on gene expression. At $15 \mathrm{dph}$, IGF-1 was significantly downregulated in fish fed RA0 (downregulation factor 5.60; $P<0.01$ ) (Fig. 7(a)) compared with the control group, whereas it was significantly upregulated at $21 \mathrm{dph}$ (upregulation factor 5.8; $P<0 \cdot 05$ ). At $21 \mathrm{dph}$, a higher $\mathrm{RXR} \alpha$ expression was also noted (upregulation factor $4.4 ; P<0.05$ ) with respect to the control group. At $42 \mathrm{dph}$, the only significant difference was observed for RAR $\gamma$, which was downregulated 3.08-fold compared with the RA50 group $(P<0.001)$. It is interesting to note that $\mathrm{RXR} \alpha$ expression was five times higher in the RA0 compared with the control group, even though this was not significant $(P<0 \cdot 07)$.

In fish fed RA1000 (Fig. 7(b)), the most striking gene regulation was observed at $10 \mathrm{dph}$ for RAR $\gamma$, which was upregulated by a factor of 82.49 compared with the control group. Other genes were significantly upregulated in larvae fed RA1000 compared with RA50 at $15 \mathrm{dph},(\mathrm{RAR} \alpha$ by $4 \cdot 4 ; P<0 \cdot 05), 21 \mathrm{dph}$ (IGF-1 by 7.06; $P<0.05)$ and $42 \mathrm{dph}(\mathrm{RXR} \alpha$ by $8.26 ; P<0.05)$.

\section{Discussion}

Recommendations on vitamin requirements for marine fish larvae are generally based on data obtained for the juveniles of cold freshwater species, such as salmonids (National Research Council, 1993). The vitamin requirements of salmonids were, however, overestimated owing to the water-soluble nature of the diets used in early studies on these requirements (Kaushik et al. 1998). Quantitative data on the dietary vitamin requirements for marine fish larvae are scarce (Gouillou-Coustans \& Guillaume, 2001).

For many years, experiments on larval nutrition were conducted with dietary formulations close to those used for the juvenile stages, but the diets leading to good performance in juveniles induced high mortality and very poor growth in larvae (Cahu et al. 2003a). The lack of a compound diet for the early fish larval stages has been the main limiting factor in establishing their nutritional requirements. In current rearing practice, marine fish larvae are generally fed live prey, rotifers and Artemia.
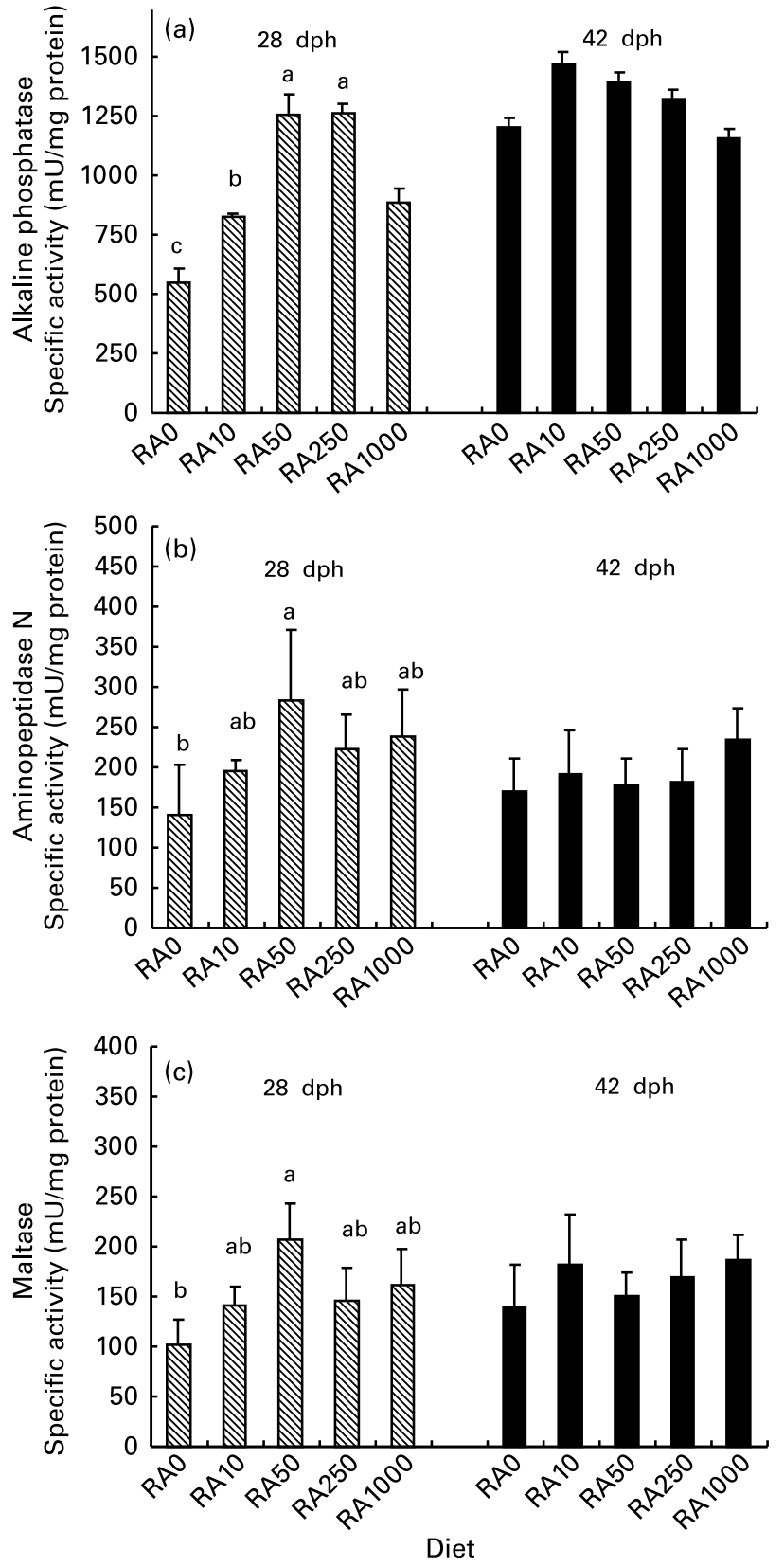

Fig. 5. Specific activity of alkaline phosphatase (a), aminopeptidase $\mathrm{N}$ (b) and maltase (c) of the intestinal brush border in European sea bass at 28 and 42 days post-hatching (dph). Values shown are means for three samples with standard deviations shown by vertical bars and different superscript letters for the same day designate significant differences $(P<0.05)$. RA, retinyl acetate.

These feeding strategies make it difficult to perform accurate nutritional studies because of the variability of the nutrient content, especially vitamins, in live prey. However, the recent development of a balanced compound diet for first feeding

Fig. 4. Retinol dietary-induced malformations in European sea bass juveniles. (a) Head of a normal fish. (b) Fish with a partially undeveloped operculum (*). (c) Deformed head with reduced neurocranium (nc) and severe anomalies in the splanchnocranium (pm, premaxilla; m, maxilla d, dentary; o, operculum) resulting in mouth prognosis $(\rightarrow)$. (d) Deformed basibranchial $(\mathrm{b})$ and hypohyal $(\mathrm{h})$ cartilages of the splanchnocranium and undeveloped neurocranium (nc) in an abnormal fish head. (e) Normal (upper image) and scoliotic (lower image) European sea bass juvenile. Lordosis and kyphosis are indicated by $\downarrow$ an arrow and *, respectively. 
Effect of age

(42 dph compared with $10 \mathrm{dph}$ )

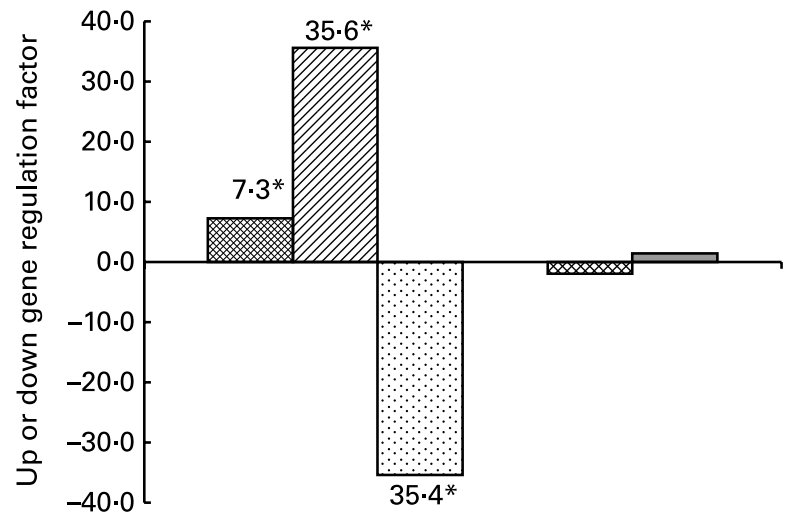

Fig. 6. Influence of age (between 10 and 42 days post-hatching (dph)) in European sea bass larvae control group fed retinyl acetate (RA) 50. Gene

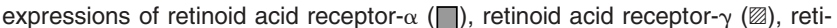
noid $X$ receptor- $\alpha$ (囷), bone morphogenetic protein-4 (网) and insulin-like growth factor-1 (回) at $42 \mathrm{dph}$ were normalised to the values obtained at $10 \mathrm{dph}$ in the control group. The numbers indicate the relative gene expression ratio. Mean values were significantly different between 42 and $10 \mathrm{dph}{ }^{*} P<0.05$

marine fish larvae (Cahu et al. 2003a) provided an opportunity to conduct nutritional experiments and evaluate the effect of dietary molecules on early fish development. Compound diets contain fish meal that mainly provides proteins and also significant amounts of some nutrients such as fatty acids, minerals and

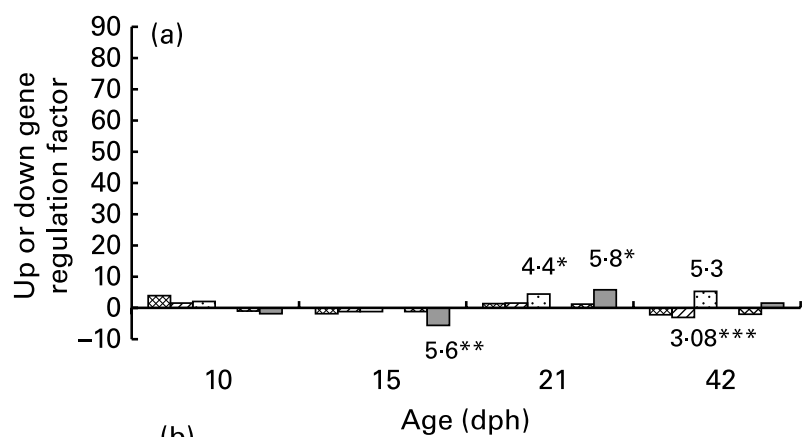

(b)

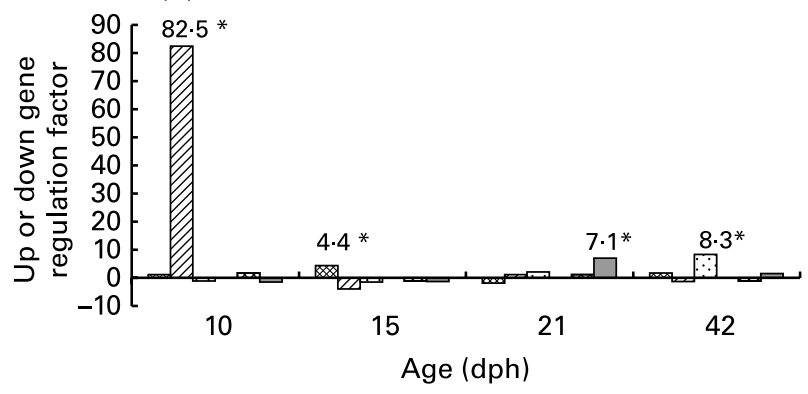

Fig. 7. Effect of retinyl acetate (RA) 0 (a) and RA1000 (b) diets in European sea bass larvae. Expressions of retinoid acid receptor- $\alpha(\mathbb{Q})$, retinoid acid

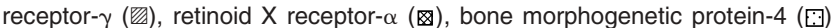
and insulin-like growth factor-1 (⿴囗十) at 10, 15, 21 and 42 days post-hatching (dph) were normalised by their corresponding values in RA50 group at the same dates. The numbers indicate the relative gene expression ratio. Mean values were significantly different within the same developmental stage compared with the RA50 group: ${ }^{*} P<0.05,{ }^{* *} P<0.01,{ }^{* * *} P<0.001$. vitamins such as vitamin A. Therefore, the real dosage of these nutrients in the experimental diets is always slightly different from the theoretical formulation.

At the end of the experiment, fish weight gain was affected by the level of dietary retinol. Under our experimental conditions, the group of larvae fed the diet containing the intermediate level of retinol (RA50) was considered to be the control group, since the dietary formulation, especially the vitamin composition, was similar to that previously described (Cahu et al. 2003a) as assuring the optimal growth and survival of animals. In comparison, larvae fed extreme levels of retinol (RA0 and RA1000 diets) were $19 \%$ and $27 \%$ lower in final weight with respect to the control diet group. As previously shown in Japanese flounder (Dedi et al. 1997; Haga et al. 2003) and Atlantic salmon (Ornsrud et al. 2002), high dietary doses of vitamin A led to lower growth. In our case, the growth reduction was particularly observed with the RA1000 diet and was associated with an increase in both circulating and accumulation forms of retinol, which probably reveals a hypervitaminosis in larvae. Low levels of dietary retinol also reduced larval growth in Japanese flounder (Dedi et al. 1997). In our study, the final body weight of European sea bass fed RA0 was lower than that of the control group.

A complete absence of retinol in the diet would have been lethal, but this had not been observed because of the incorporation in experimental diets of fish meal containing a low amount of different vitamins. Survival followed a similar trend to growth and was affected both by low and high dietary levels of alltrans retinol. It should be pointed out that a survival percentage higher than $50 \%$ (obtained in the control and RA10 groups) is generally considered as very good in seabass larva-rearing (Cahu \& Zambonino Infante, 2001); the survival percentage obtained in the control group, in addition to the growth data, ensured that valid physiological and nutritional observations could be drawn from this study.

Previous studies have shown that the pancreatic and intestinal enzyme activity provides a reliable marker of larval fish development (Péres et al. 1998; Zambonino Infante \& Cahu, 1999). Under the experimental conditions described here, an excess of dietary all-trans retinol (RA1000) resulted in low trypsin secretion ratio; this effect cannot be attributed to the different nature or quantity of dietary proteins, as shown by several authors (Cahu \& Zambonino Infante, 2001), since all the diets tested had the same protein sources and levels. A low trypsin secretion ratio at the end of the larval period might indicate a delay in the maturational process of the pancreas (Cahu \& Zambonino Infante, 2001). It is well known that pancreatic differentiation is controlled by thyroid hormones, whose receptors interact with those of retinoids (Kobayashi et al. 2002). It can be suggested that high levels of vitamin A might induce a disruption of this signalling pathway, affecting the maturation of the pancreas and consequently its secretory functions.

European sea bass larvae normally achieve complete development of their digestive tract around the fourth week of life, with the onset of the brush border membrane digestion of enterocytes concurrent with the decline of cytosolic digestion. This maturational process is well known in mammals (Henning, 1987) and has been also described in fish (Zambonino Infante et al. 1997; Zambonino Infante \& Cahu, 1999). Vitamin A interferes with the normal development of chicken and rat intestinal mucosa as it influences enterocyte proliferation and maturation (Reifen et al. 1998; Uni et al. 2000) and decreases brush border enzyme-specific activity (Uni et al. 2000). In our study, fish fed RA0 exhibited the lowest specific activities in 
the three brush border enzymes studied at $28 \mathrm{dph}$. This reflected the lower stage of development of larvae fed RA0 compared with those from other groups. The maturation of intestinal brush border enzymes normally takes place between 20 and $30 \mathrm{dph}$ in European sea bass, and this maturation process is generally completed by the end of the larval period ( $42 \mathrm{dph}$; Zambonino Infante \& Cahu, 1999).

Retinoids are essential for normal embryonic development through their direct or indirect action on gene families such as Hox (Joore et al. 1994; Krumlauf, 1994), shh (Helms et al. 1997), BMP (Yates et al. 2002) or IGF (Allan et al. 2003) that are involved in morphogenesis. Any perturbation of these pathways interferes with normal body patterning, leading to abnormalities such as albinism and jaw or vertebral column deformities (Haga et al. 2002, 2003). Retinoids exert their teratogenic effects via their receptors, and a major involvement of RAR, especially RAR $\gamma$, has previously been demonstrated in the appearance of malformations, compared with RXR (Ross et al. 2000). Nevertheless, RXR are essential in transducing the retinoid signal for a large number of retinoic aciddependent processes because the RAR/RXR heterodimers are the functional units (Ross et al. 2000).

In the present study, fish fed RA50 (control group) exhibited a decrease in $\operatorname{RXR} \alpha$ expression between 10 and $42 \mathrm{dph}$, probably reflecting the need for such receptors during differentiation processes in the early development of European sea bass. Afterwards, their synthesis slowed down as the cells underwent less of a differentiation process. In fish fed RA0, the presence of maternal retinol in the yolk sac could have balanced the lack of dietary vitamin A during the early stages of development and could have been responsible for the absence of significant difference in the gene expression pattern compared with the RA50 group. Up to $21 \mathrm{dph}$, no difference in RAR $\alpha$ and RAR $\gamma$ expression was observed. RXR $\alpha$ was upregulated at $21 \mathrm{dph}$ (by a factor of 6.75), but, as mentioned earlier, its role in the teratogenic retinoic acid signal is not major compared with that of RAR $\gamma$. Taken together, these data may explain the very low percentage of malformed fish in this experimental group. The low level of dietary vitamin A (RA0) affected RAR $\gamma$ expression only between 21 and $42 \mathrm{dph}$, which seemed to be too late to perturb the morphogenesis as European sea bass already have adult features at this age.

Since RA0 larvae exhibited significant variations in IGF-1 expression at $15 \mathrm{dph}$ (by a factor of -5.6) and $21 \mathrm{dph}$ (by a factor of 8.9) compared with the reference group, the downregulation at $15 \mathrm{dph}$ may be linked to a vitamin A deficiency. Indeed, the same IGF-1 downregulation had previously been observed in the Japanese quail (Fu et al. 2001), correlated to an increase in the expression of the IGF-1 receptor, which may maximise the effect of this signalling molecule. We did not study the IGF-1 receptor gene, but we can hypothesise that the IGF-1 downregulation observed in the present study was most likely linked to an increase in the IGF-1 receptor at day 15. Such a regulation of IGF-1 could exert positive feedback in a second phase and lead to the IGF-1 upregulation at $21 \mathrm{dph}$.

Another hypothesis could also explain the down/upregulation of IGF-1. This gene belongs to the family of genes that are potentially inducible by retinoic acid (Gabbitas \& Canalis, 1997) as it has a high probability of possessing a retinoic acid response element in its promoter (Balmer \& Blomhoff, 2002). The increased expression of IGF-1 at day 21, in the absence of its inductor, may play a conservative role by preventing a significant decrease in IGF-1, at least over a short period. Such preven- tive mechanisms have been observed in young animals suffering from malnutrition and have been particularly studied for digestive enzymes in mammals (Raul et al. 1982) and in fish (Cahu \& Zambonino Infante, 1994). This increase, taken together with the abnormal expression of RXR at 21 and $42 \mathrm{dph}$, may reflect a disorder of cellular function. The lack of vitamin A may have been partially balanced by the maternal retinol of the yolk sac during the early stages of development and by an insufficient endogenous production of retinoic acid after the resorption of the vitelus as the larvae showed retarded growth.

Using RAR $\gamma$-null mutant mice, it has been shown that this RAR sub-type may be required for the teratogenic retinoic acid signal in the generation of the trunk but not for the craniofacial skeletal abnormalities. Moreover, RAR $\gamma$-null mice were resistant to high doses of retinoic acid, indicating that RAR $\gamma$ may play a major role in mediating retinoid toxicity (Ross et al. 2000). These findings must be considered with those of the present study: at $10 \mathrm{dph}$, fish fed RA1000 exhibited an RAR $\gamma$ expression 82.5 times higher than that of the reference group, as well as the highest percentage of malformations. As these malformations mainly affected the maxilla and the neurocranium, we may assume that the genes involved in fish and controlled by RAR are different from those in mice, or that the vertebra were too differentiated to be perturbed. Several studies demonstrated the implication of shh and hoxd-4 (Suzuki et al. 1998), which possess retinoic acid responsive elements, in malformations affecting pharyngeal arch development in Japanese flounder treated with retinoic acid (Suzuki et al. 2000). Haga et al. (2002) showed that the expression of RAR, without any distinction between sub-families, increased after 3 days of treatment with retinoic acid and was linked to jaw deformities, whereas the expression of RXR did not seem to be affected. Our study showed that it was in fact RAR $\gamma$ sub-family expression that was increasing. Moreover, we noted a significant increase in RXR $\alpha$ expression at $42 \mathrm{dph}$ compared with the RA50 group, suggesting that fish fed RA1000, like larvae fed RA0, exhibit functional disorders. Retinoic acid is thought to induce abnormalities by shifting the border of expression of Hox genes and eventually causing a transformation of anterior cell fates to more posterior cell fates (Suzuki et al. 1998).

These skeletal abnormalities may also involve IGF-1 and BMP-4. It has been demonstrated that retinoic acid can enhance IGF-1 expression and affect the development of limbs (Qin et al. 2002), whereas BMP-2 and BMP-4 are thought to be mediators of the osteogenic actions of growth hormone and IGF-1 ( $\mathrm{Li}$ et al. 1998) and to be responsible for bone and tooth formation. Retinoic acid can also cooperate with BMPs during osteoblast differentiation even though BMP-4 does not have any retinoic acid response elements in its promoting region (Balmer $\&$ Blomhoff, 2002). This may explain why we did not observe any significant variation in BMP-4 expression during our experiment. The linear correlation between vitamin A content in larvae and the malformation percentages observed in this study, coupled with data from other authors (Conlon, 1995; Suzuki et al. 1998, 2000; Haga et al. 2002, 2003), might indicate that disruption of the signalling pathway of retinoid nuclear receptors results in a perturbation of cell differentiation and development, finally leading to skeletal malformations.

In fish, several studies have demonstrated that retinoids can affect the expression of shh, hoxd-4 and RAR genes in Japanese flounder, resulting in abnormal development of the pharyngeal skeleton and vertebral column (Suzuki et al. 1998, 2000; Haga et al. 2002, 2003). Similarly, the present data showed that 
unbalanced levels of dietary all-trans retinol resulted in an alteration of head organisation in European sea bass juveniles, which was characterised by abnormal development of the operculum, premaxillary, maxillary, dentary and neurocranium, and basibranchial and hypohyal cartilages. Malformations were not only observed in the cephalic region, since a moderate number of fish also showed scoliosis in their vertebral column. The possible involvement of Hoxd-4 and shh genes in the development of the pharyngeal skeleton and vertebral column in sea bass larvae deserves to be studied.

It is interesting to note that experiments with marine fish larvae allow skeletal malformations to be induced via a nutritional pathway. Other species used as biological models, for example zebrafish (Joore et al. 1994), hatch at a later developmental stage than marine fish larvae (Barnabé et al. 1976; Kimmel et al. 1995). Therefore, abnormalities induced by retinoic acid have so far been observed in experiments conducted under non-nutritional conditions during embryogenesis, for example by implanting beads soaked in retinoic acid in chicken embryos (Lee et al. 2001), by bathing Xenopus embryos in a medium containing dissolved retinoic acid (Minucci et al. 1996) or by rearing Japanese flounder embryos in water containing controlled concentrations of retinoic acid (Suzuki et al. 1998, 2000; Haga et al. 2003).

Results related to body weight gain, maturation of the digestive system and incidence of malformations indicate that the optimal dietary level of vitamin A for European sea bass larvae was around $31 \mathrm{mg} / \mathrm{kg}$ DM (RA50 diet), which is much higher than the requirement of $0.75 \mathrm{mg} / \mathrm{kg} \mathrm{DM}$ reported for salmonid juveniles (National Research Council, 1993). These results seemed to indicate that vitamin A requirements depend on the stage of development (Gouillou-Coustans et al. 1998), since the specific growth rate of larvae is higher than that of older fish, and differentiation and morphogenetic processes are very intense during this period to achieve the juvenile/adult phenotype.

In conclusion, the optimal dietary retinol level for a harmonious development of sea bass larvae was close to $31 \mathrm{mg} / \mathrm{kg}$ DM. The observed linear correlation between vitamin A level in larvae and malformation percentage was linked to a modification in $\operatorname{RXR} \alpha, \operatorname{RAR} \alpha$ and RAR $\gamma$ expression patterns, whereas BMP-4 and IGF-1 expressions were not affected by dietary retinol doses. This demonstrates the influence of nutrition on the retinoid pathways that play an important role in body patterning and the induction of skeletal malformations during post-hatching development in European sea bass.

\section{Acknowledgements}

The authors wish to thank P. Quazuguel and M. M. Le Gall for their excellent technical assistance during larval rearing and sample analysis. L Villeneuve and E Gisbert were supported by an IFREMER-INRA grant and EC Marie Curie Individual Fellowship (QLK-CT-2001-52 009), respectively.

\section{References}

Allan GJ, Zannoni A, McKinnel I, Oho WR, Holzenberger M, Flint DJ \& Patel K (2003) Major components of the insulin-like growth factor axis are expressed early in chicken embryogenesis, with IGF binding protein (IGFBP)-5 expression subject to regulation by Sonic Hedgehog. Anat Embryol 207, 73-84.
Balmer JE \& Blomhoff R (2002) Gene expression regulation by retinoic acid. J Lipid Res 43, 1773-1808.

Barnabé G, Boulineau-Coatanea F \& Rene F (1976) Chronologie de la morphogenèse chez le loup ou bar Dicentrarchus labrax (L.) (Pisces Serranidae) obtenu par reproduction artificielle. Aquaculture 8, $351-363$.

Bessey OA, Lowry OH \& Brock MJ (1946) Rapid coloric method for determination of alkaline phosphatase in five cubic millimeters of serum. J Biol Chem 164, 321-329.

Bradford MM (1976) A rapid and sensitive method for the quantitation of microgram quantities of protein utilizing the principle of protein-dye binding. Anal Biochem 72, 248-254.

Cahu CL \& Zambonino Infante JL (1994) Early weaning of sea bass (Dicentrarchus labrax) larvae with a compound diet: effect on digestive enzymes. Comp Biochem Physiol 109A, 213-222.

Cahu CL \& Zambonino Infante JL (2001) Substitution of live food by formulated diets in marine fish larvae. Aquaculture 200, 161-180.

Cahu CL, Zambonino Infante JL \& Barbosa V (2003a) Effect of dietary phospholipid level and phospholipid:neutral lipid value on the development of sea bass (Dicentrarchus labrax) larvae fed a compound diet. $\mathrm{Br}$ J Nutr 90, 21-28.

Cahu C, Zambonino Infante J \& Takeuchi T (2003b) Nutritional components affecting skeletal development in fish larvae. Aquaculture 227, 245-258.

Cohlan SQ (1953) Excessive intakes of vitamin A as a cause of congenital anomalies in the rat. Science 117, 535-536.

Conlon RA (1995) Retinoic acid and pattern formation in vertebrates. Trends Genet 11, 314-319.

Crane RK, Boge G \& Rigal A (1979) Isolation of brush border membranes in vesicular form from the intestinal spiral valve of the small dogfish (Scyliorhinus canicula). Biochim Biophys Acta 554, 264-267.

Dagnelie P (1975) Les méthodes de l'inférence statistique. In Théorie et méthodes statistiques, Vol. 2, pp. 1-463 [J Ducolot, editor]. Gembloux, Belgium: Les Presses Agronomiques de Gembloux.

Dahlqvist A (1970) Assay of intestinal disaccharidase. Enzym Biol Clin 11, $52-56$.

Dedi J, Takeuchi T, Seikai T, Watanabe T \& Hosaya K (1997) Hypervitaminosis A during vertebral morphogenesis in larval Japanese flounder. Fish Sci 63, 466-473.

Fu Z, Noguchi T \& Kato H (2001) Vitamin A deficiency reduces insulinlike growth factor (IGF)-I gene expression and increases IGF-I receptor and insulin receptor gene expression in tissues of Japanese Quail (Coturnix coturnix japonica). J Nutr 131, 1189-1194.

Gabbitas B \& Canalis E (1997) Retinoic acid regulates the expression of insulin-like growth factors I and II in osteoblasts. J Cell Physiol 172, 253-264.

Gause WC \& Adamovicz J (1994) The use of the PCR to quantitate gene expression. PCR Methods Appl 3, 123-135.

Gouillou-Coustans MF \& Guillaume J (2001) Vitamin nutrition. In Nutrition and Feeding of Fish and Crustaceans, pp. 145-166 [J Guillaume, SJ Kaushik, P Bergot and R Metallier, editors]. Chichester: SpringerPraxis.

Gouillou-Coustans MF, Bergot P \& Kaushik SJ (1998) Dietary ascorbic acid needs of common carp (Cyprinus carpio) larvae. Aquaculture 161, 453-461.

Grolier P, Agoudavi S \& Azais-Braesco V (1995) Comparative bioavailability of diet-, oil- and emulsion-based preparations of vitamin A and b-carotene in rat. Nutrition Res 15, 1507-1516.

Haga Y, Suzuki T, Kagechika H \& Takeuchi T (2003) A retinoic acid receptor-selective agonist causes jaw deformity in the Japanese flounder. Paralichthys olivaceus. Aquaculture 221, 381-392.

Haga Y, Suzuki T \& Takeuchi T (2002) Retinoic acid isomers produce malformations in postembryonic development of the Japanese flounder, Paralichthys olivaceus. Zool Sci 19, 1105-1112.

Helms JA, Kim CH, Hu D, Minkoff R, Thaller C \& Eichele G (1997) Sonic hedgehog participates in cranofacial morphogenesis and is down-regulated by teratogenic doses of retinoic acid. Dev Biol 187, 25-35. 
Henning SJ (1987) Functional development of the gastrointestinal tract. In Physiology of the Gastrointestinal Tract, pp. 285-300 [LR Johnson, editor]. New York: Raven Press.

Hogan BL (1996) Bone morphogenic proteins: multifunctional regulators of vertebrate development. Gene Dev 10, 1580-1594.

Holm H, Hanssen LE, Krogdahl A \& Florholmen J (1988) High and low inhibitor soybean meals affect human duodenal proteinase activity differently: in vivo comparison with bovine serum albumin. $J$ Nutr 118, $515-520$.

Joore J, Van Der Lans GBLJ, Lanser PH, Vervaart JM, Zivkovic D, Speksnijder JE \& Kruijer W (1994) Effects of retinoic acid on the expression of retinoic acid receptors during zebrafish embryogenesis. Mech Dev 46, 137-150.

Kaushik SJ, Gouillou-Coustans MF \& Cho CY (1998) Application of the recommendations on vitamin requirements of finfish by NRC (1993) to salmonids and sea bass using practical and purified diets. Aquaculture 161, 463-474.

Kimmel CB, Ballard WW, Kimmel SR, Ullman B \& Schilling TF (1995) Stages of embryonic development of the zebrafish. Dev Dyn $\mathbf{2 0 3}$ 253-310.

Kobayashi H, Spilde TL, Bhatia AM, Scita G, DeLuca LM, Taira M, Levin AA, Ozato K \& David IB (2002) Retinoid signaling controls mouse pancreatic exocrine lineage selection through epithelialmesenchymal interactions. Gastroenterology 123, 1331-1340.

Krumlauf R (1994) Hox genes in vertebrate development. Cell 78, $191-201$

Lee SH, Fu KK, Hui JN \& Richma JM (2001) Noggin and retinoic acid transform the identity of avian facial prominences. Nature $\mathbf{4 1 4}$, 909-912.

Li H, Bartold PM, Zhang CZ, Clarkson RW, Young WG \& Waters MJ (1998) Growth hormone and insulin-like growth factor I induce bone morphogenetic proteins 2 and 4: a mediator role in bone and tooth formation? Endocrinology 139, 3855-3862.

Maroux S, Louvard D \& Baratti J (1973) The aminopeptidase from hogintestinal brush border. Biochim Biophys Acta 321, 282-295.

Minucci S, Saint-Jeannet JP, Toyama R, Bichingham BB, Hembree MJ, Prasadan K, Preuett BL, Imamurea M \& Gittes GK (1996) Retinoic $\mathrm{X}$ receptor-selective ligands produce malformations in Xenopus embryos. Proc Natl Acad Sci U S A 93, 1803-1807.

National Research Council (1985) Guide for the Care and Use of the Laboratory Animals. Publication no. 85-23 (rev.). Bethesda, MD: National Institutes of Health.

National Research Council (1993) Nutrient Requirements of Fish. Washington, DC: National Academy Press.

Ornsrud R, Graff IE, Hoie S, Totland GK \& Hemre GI (2002) Hypervitaminosis A in first-feeding fry of the Atlantic salmon (Salmo salar L.). Aquac Nutr 8, 7-13.
Péres A, Zambonino Infante JL \& Cahu CL (1998) Dietary regulation of activities and mRNA levels of trypsin and amylase in sea bass (Dicentrarchus labrax) larvae. Fish Physiol Biochem 19, 145-152.

Pfaffl MW (2001) A new mathematical model for relative quantification in real-time RT-PCR. Nucleic Acids Res 29, 2002-2007.

Pfaffl MW, Horgan GW \& Dempfle L (2002) Relative expression software tool (RESTC) for group-wise comparison and statistical analysis of relative expression results in real-time PCR. Nucleic Acids Res 30, 9-36.

Qin P, Cimildoro R, Kochhar DM, Soprano KJ \& Robert Soprano D (2002) PBX, MEIS, and IGF-I are potential mediators of retinoic acid-induced proximodistal limb reduction defects. Teratology $\mathbf{6 6}$, 224-234.

Raul F, Noriega R, Doffoel M, Grenier JF \& Haffen K (1982) Modifications of brush border enzyme activities during starvation in the jejunum and ileum of adult rats. Enzyme 28, 328-335.

Reifen R, Zaiger G \& Uni Z (1998) Effect of vitamin A on small intestinal brush border enzymes in a rat. Int J Vitam Nutr Res $\mathbf{6 8}$, 281-286.

Ross SA, McCaffery PJ, Drager UC \& De Luca LM (2000) Retinoids in embryonal development. Physiol Rev 80, 1021-1054.

Suzuki T, Oohara I \& Kurokawa T (1998) Hoxd-4 expression during pharyngeal arch development in flounder (Paralichthys olivaceus) embryos and effects of retinoic acid on expression. Zool Sci 15, 57-67.

Suzuki T, Srivastava AS \& Kurokawa T (2000) Experimental induction of jaw, gill and pectoral fin malformations in Japanese flounder, Paralichthys olivaceus, larvae. Aquaculture 185, 175-187.

Uni Z, Zaiger G, Gal-Garber O, Pines M, Rozenboim I \& Reifen R (2000) Vitamin A deficiency interferes with proliferation and maturation of cells in the chicken small intestine. Br Poult Sci 41, 410-415.

Yates KE, Troulis MJ, Kaban LB \& Glowacki J (2002) IGF-I, TGF- $\beta$, and BMP-4 are expressed during distraction osteogenesis of the pig mandible. Int J Oral Maxillofac Surg 31, 173-178.

Yu VC, Delsert C, Andersen B, Holloway JM, Devary OV, Näär AM, Kim SY, Boutin JM, Glass CK \& Rosenfeld MG (1991) RXRß: a coregulator that enhances binding of retinoic acid, thyroid hormone, and vitamin D receptors to their cognate response elements. Cell 67, $1251-1266$

Zambonino Infante JL \& Cahu CL (1999) High dietary lipids levels enhance digestive tract maturation and improve Dicentrarchus labrax larval development. J Nutr 129, 1195-1200.

Zambonino Infante JL, Cahu CL \& Péres A (1997) Partial substitution of di- and tripeptides for native protein in sea bass diet improves Dicentrarchus labrax larval development. J Nutr 127, 604-614.

Zizola CF, Balaña ME, Sandoval M \& Calvo JC (2002) Changes in IGF-I receptor and IGF-I mRNA during differentiation of 3T3-L1 preadipocytes. Biochimie 84, 975-980. 